\title{
Paikat, tilat ja yliluonnollinen
}

\author{
Supernatural Places Revisited - The Spatial Dimensions of Folklore and Sagas \\ -symposiumi 5.6.2018 Tartossa
}

Pasi Enges

Tarton yliopistossa järjestettiin kesäkuussa 2012 pohjoismais-kelttiläis-balttilainen L Supernatural Places -symposiumi, joka keräsi paikalle yli sata tutkijaa eri puolilta maailmaa. Tuolloin kuultiin neljän päivän aikana Bengt af Klintbergin pitämän keynote-luennon lisäksi kymmenen plenaariluentoa ja noin 60 teemaan kytkeytyvää tieteellistä esitelmää. Tasan kuusi vuotta myöhemmin saman aihepiirin ympärille järjestetty Supernatural Places Revisited -symposiumi oli huomattavasti pienempi tapahtuma. Ennen kaikkea yksipäiväisellä symposiumilla haluttiin juhlia kesän 2012 luentoihin ja esitelmiin pohjautuvan Storied and Supernatural Places -teoksen (Valk \& Sävborg 2018) ilmestymistä, mutta se tarjosi myös mielenkiintoisia puheenvuoroja ja uutta ajattelemisen aihetta paikoista ja niiden erilaisista merkityksistä kiinnostuneille kuulijoille. Yliopiston päärakennuksessa pidetyn tilaisuuden yleisö vaihteli päivän mittaan, ja yhteensä kuulijoita oli arviolta nelisenkymmentä.

\section{Teemana yliluonnolliset paikat ja maisemat}

Paikat ja maisemat eivät ole pelkästään maantieteellisiä sijainteja, vaan tapahtumien, muistojen ja kertomusten näyttämöitä. Otsikkonsa mukaisesti symposiumi keskittyi paikkojen ja maisemien yliluonnollisiin ulottuvuuksiin, ja yliluonnollisen spatiaalisuutta lähestyttiin erityisesti folkloren ja pohjoismaisen saagakirjallisuuden tarjoamista lähtökohdista. Näkökulman rajaus on ymmärrettävä, sillä symposiumin järjestämisestä vastasivat Tarton yliopiston folkloristiikan professori Ülo Valk ja Skandinavian tutkimuksen professori Daniel Sävborg, jotka ovat myös edellä mainitun artikkelikokoelman toimittajat.

Varsinaista keynote-esitelmää ei tällä kertaa ollut, mutta ensimmäiselle puhujalle oli varattu muita pitempi esiintymisaika, joten Frogin esityksestä tavallaan tuli sellainen. Otsikolla "Otherworlding: Othering Geographical Places and Spaces through Mythologization" hän esitteli kehittelemäänsä otherworlding-käsitettä, jonka perustana on toiseuttamisen (othering) käsite. Perusajatus on, että paikkojen ja tilojen mytologisaatio tapahtuu diskursiivisesti ja voi koskea yhtä hyvin puhtaasti kuvitteellisia kuin reaalisiakin kohteita. Mytologisaatiossa mielikuvat muuttuvat luonnolliseksi osaksi sosiaalisesti havaittua todellisuutta. Frog valaisi esimerkein (kuten Inarinjärven Ukonsaari) paikkojen ja tilojen syntyprosesseja ja erilaisia paikan perustyyppejä. Frogin puheenvuoro oli päivän esityksistä teoreettisesti antoisin ja herätti paljon keskustelua. Ülo Valknosti esiin kysymyksen mielikuvien genresidonnaisuuden 
ja niihin uskomisen välisestä suhteesta. Frogin näkemys oli, että otherworlding perustuu eri lajeissa erilaisiin mielikuviin/embleemeihin, jotka ovat lajikohtaisesti itsenäisiä ja joilla ei välttämättä ole lajit ylittävää vuorovaikutusta. - Tulevaisuudessa on mielenkiintoista nähdä, miten Frog kehittää otherworlding-käsitettä, minkälaisia sovellusmahdollisuuksia sille löytyy ja minkälaisen suomenkielisen muodon se mahdollisesti saa.

Islannin yliopistoa edustavan kirjallisuustieteilijä Arngrimur Vídalínin esitelmä koski pahuuden sijaintipaikkoja saagoissa. Saagakirjallisuudessa pahuus ruumiillistuu esimerkiksi peikkoihin, hirviöihin ja lainsuojattomiin, mutta Vídalín ei käsitellyt yksilöityä pahuutta, vaan yhteiskunnan järjestystä uhkaavaa, essentiaalista pahaa, jonka olemassaolo on välttämätöntä "meidän" (sivistyneiden ja moraalisten) ja "niiden" välisen eron tekemiseksi. Pahan on sijaittava aina jossakin, ja saagoissa se yhdistetään konkreettisiin paikkoihin, alueisiin ja ilmansuuntiin. On myös ilmeistä, että kristillinen oppi on vaikuttanut voimakkaasti saagojen pahuuskäsityksiin ja -kuvauksiin.

Folkloristi Tommy Kuusela Tukholman yliopistosta käsitteli esityksessään metsää yliluonnollisten kohtaamisten tapahtumapaikkana skandinaavisessa perinteessä. Hän aloitti saagakirjallisuuden kuvauksista metsässä asustavien olentojen kohtaamisesta ja siirtyi sitten käsittelemään folkloreaineistoja ja niissä kuvattuja uskomusolentoja. Skandinaviassa naispuoliset olennot ovat selvästi miespuolisia yleisempiä, mikä Kuuselan mukaan on yksi keskeinen alueen perinnettä luonnehtiva piirre. Hän myös totesi, että skandinaavista ainesta läheisesti vastaavaa perinnettä löytyy myös Suomesta ja Venäjältä. Näiden vastaavuuksien ja erojen tarkempi osoittaminen jää tulevan tutkimuksen tehtäväksi ja vaatii kielikynnyksen ylittämiseksi maidenvälistä tutkijayhteistyötä.

Daniel Sävborg kysyi esitelmässään, edustavatko saagojen ja muiden varhaisten kirjallisten lähteiden kuvaukset tuonpuoleisesta ja sitä asuttavista olennoista todella oman aikansa maailmankuvaa vai ovatko ne pikemminkin tekijöidensä kirjallisen mielikuvituksen tuotteita. Kokonaiskuvan muodostamiseksi on otettava huomioon koko saatavilla oleva lähdeaineisto: lait (jotka muun muassa kielsivät jättiläisten ja peikkojen herättämisen!), annaalit, oppineitten kirjoitukset, Islannin löytämisestä ja saaren asuttamisesta kertova Landnámabók sekä luonnollisesti tuota aikakautta kuvaava saagakirjallisuus. Myös 1900-luvun aineistot - kuten uskomusolentojen kohtaamista kuvaavat memoraatit - ovat hyödyllisiä ilmiön ymmärtämiseksi. Tuonpuoleista koskevia käsityksiä on keskiaikaisessa Islannissa muovannut kaksi rinnakkaista diskurssia. Kansanomaisessa diskurssissa yliluonnollisia olentoja pidettiin ruumiillisina ja esimerkiksi sukusaagojen valossa ne olivat usein avuliaita ja ihmisille hyödyllisiä. Oppineitten näkemys taas oli, että olennot olivat puhtaasti aineettomia ja esimerkiksi pyhimyssaagoissa ne esitetään yksiselitteisesti olemukseltaan pahoina. Lähes kaikki tunnetut muinaisskandinaaviksi kirjoitetut tekstit ovat oppineiden kirjoittamia, mikä vinouttaa kuvaa kahden rinnakkaisen ja keskenään kilpailevan diskurssin olemassaolosta.

Ülo Valk tarkasteli otsikolla "Entangled Storyworlds" erityisiä paikkoja ja niitä koskevaa kertomusperinnettä liminaalisuuden näkökulmasta. Hän määritteli liminaalisuuden jatkuvaksi prosessiksi, alati muuttuvaksi tilaksi, jota lähtökohtaisesti voidaan tarkastella erilaisten kokijasubjektien (henkilöt, sosiaaliset ryhmät, yhteiskunnat), sekä ajallisen (hetket, ajanjaksot, epookit) ja tilallisen ulottuvuuden (rajat, alueet, valtiot ja niitä laajemmat kokonaisuudet, jopa maanosat) kautta. Paikkaperinne ja paikalle annetut merkitykset voivat olla hetkellisiä ja yksityiskohtaisia, mutta yhtä hyvin pitkäkestoisia ja kokonaisia kansakuntia koskevia. 
Esimerkkeinä nyky-Virosta Valk mainitsi onnettomuuspaikat, UFO-havaintojen paikat ja "luonnolliset pyhät paikat", jotka kaikki eri tavoin ja eri laajuudella osallistuvat Viron ja virolaisuuden rakentamiseen. Vanhassa tarinaperinteessä pyhien (luonnon)paikkojen tuhoajaa kohtaa rangaistus, kuten kuolema tai vakava onnettomuus. Nykypäivänä vastaavanlaisia varoitustarinoita voi lukea päivälehdistä. Rangaistuksen antaja ja mekanismi tosin eivät nykyään ole samalla tavoin selviä kuin entisaikoina, jolloin rangaistuksen tavallisimmin selitettiin tulevan suoraan Jumalalta. Ülo Valk myös eritteli paikkaperinnettä luonnehtivia ominaisuuksia, joista yksi keskeisimmistä on kokemuksellisuus. Paikka määritellään erityiseksi ja erotetaan ympäristöstään erilaisten diskursiivisten prosessien keinoin, mutta tarinaperinne ei yksinään tee paikkaa. Paikan erityisyys (liminaalisuus tai välitilaisuus, inbetweenness) syntyy kertomusmaailman (storyworld) ja ruumiillisten kokemusten kohdatessa. Kun yliluonnollinen on paikkaa määrittelevä elementti, tuottaa sen epävarmuus ja käsittämättömyys yhä uusia kertomuksia ja tulkintoja. Paikkaperinteen kiehtova ominaisuus onkin sen päättymätön keskeneräisyys: ei voi ajatella, että jotakin paikkaa koskeva perinne voisi saavuttaa lopullisen, pysyvän muodon.

Tarttoon kotiutuneen brittifolkloristi Jonathan Roperin esitys poikkesi päivän yleisestä linjasta. Hänen esitelmänsä "Ugly Folklore" lähti liikkeelle kauneudesta (kyseenalaisena) folkloren arvon mittarina ja keskittyi paljolti ei-yliluonnolliseen folkloreen. Hän käsitteli myös uskon ja epäuskon aspekteja niin kansanomaisessa kuin oppineessakin kontekstissa. Roperin sinänsä kiinnostavan puheenvuoron yhteys symposiumin teemaan jäi hieman hämäräksi, etenkin kun hän ei lainkaan puhunut paikoista.

Tiina Sepp on Tarton yliopistossa väitellyt ja nyt Yorkin yliopistossa postdoc-tutkimusta tekevä folkloristi. Hän esitteli Englannin katedraaleihin liittyvää, kenttätyöhön perustuvaa tutkimustaan. Tutkimusohteina ovat Canterburyn, Durhamin, Westminsterin and Yorkin katedraalit ja erilaiset niissä toimivat ryhmät, kuten oppaat, vierailijat ja pyhiinvaeltajat. Näillä kaikilla on oma näkemyksensä siitä, mikä tekee paikasta kiinnostavan ja miksi sinne tullaan. Merkityksensä on niin katedraalin arkkitehtuurilla, sen nimikkopyhimyksellä kuin paikkaan liittyvillä kertomuksillakin. Sepp pyrkii myös jäljittämään erilaisia katedraaleja yhdistävää metakertomusta, vaikka suhtautuukin - paikkojen erilaisista historioista johtuen -epäillen mahdollisuuteen löytää sellainen.

Päivän viimeisestä puheenvuorosta vastasi Tarton yliopiston folkloristiikan oppiaineessa tutkijana työskentelevä Kristel Kivari. Hän käsitteli esityksessään Viron Harjumaalla sijaitsevan Tuhalan luonnonsuojelualuetta, jolla sijaitsee suuri määrä muinaismuistoja, kuten esihistoriallisia asuinpaikkoja ja kalmistoja sekä kymmenittäin kulttikiviä. Sen tunnetuin nähtävyys on Noitakaivo (Nõiakaev), joka ajoittain "kiehuu" alueella virtaavan maanalaisen joen tulviessa. Kaivon viereen on pystytetty energiapylväs, jonka väitetään johtavan maanalaista energiaa. Alueeseen liittyy taloudellisia, kulttuuripoliittisia että henkisiä intressejä: sitä markkinoidaan aktiivisesti turisteille, mutta samalla sitä halutaan suojella kansallisena kulttuuriperintönä ja se on erilaisten New Age -käytänteiden kohde ja tapahtumapaikka. Suojelualue on esimerkki paikasta, jossa aineelliset ja aineettomat arvot ja niitä perustelevat kertomukset kohtaavat. 


\section{Tutkittavaa riittää}

Symposiumipäivän tieteellinen kattaus oli monipuolinen ja kiinnostava. Niin virallisen osuuden päättäneessä kirjan julkistustilaisuudessa kuin myöhemmin illallisella esitetyissä puheenvuoroissa toistui huomio, että paikat, tilat ja maisemat yliluonnollisine ulottuvuuksineen on laaja tutkimuskohde, jota ei ole mahdollista ammentaa loppuun yhden tai kahdenkaan symposiumin raameissa. Jatkoa siis on odotettavissa, jos ei lähiaikoina suurempana tieteellisenä tilaisuutena, ainakin symposiumiin osallistuneiden ja muiden tutkijoiden omien töiden puitteissa.

Lopuksi vielä pieni terminologinen huomio. Yliluonnollinen on paljon kritisoitu käsite: sitä on pidetty tutkijoiden tieteellisen maailmankuvan paremmuutta perustelevana, etnosentrisenä ja tutkimuksen kohteena olevien ihmisten omaa kokemusta väheksyvänä. Analyyttisena käsitteenä se kieltämättä on ongelmallinen, mutta myös vaikeasti korvattavissa millään muulla käsitteellä. (Enges 2012, 63-66.) Kuvailevana käsitteenä se on kuitenkin hyvin käyttökelpoinen. Vuosien 2012 ja 2018 symposiumien järjestäjät ja esiintyjät käyttivät sitä varsin ongelmattomasti, ja niin olen minäkin tehnyt yllä olevassa tekstissä sekä muissa yhteyksissä. Kuullessaan sanaparin "yliluonnollinen paikka" yhteisen kiinnostuksen kohteen jakavat ja akateemiselta taustaltaan toistensa kaltaiset tutkijat tietävät, mistä ainakin suunnilleen on kysymys.

\section{Kirjallisuus}

Enges, Pasi. 2012. "Minä melkein uskon": Yliluonnollinen ja sen kohtaaminen tenonsaamelaisessa uskomusperinteessä. Turku: Turun yliopisto.

Valk, Ülo ja Daniel Sävborg (toim.) 2018: Storied and Supernatural Places: Studies in Spatial and Social Dimensions of Folklore and Sagas. Helsinki: Finnish Literature Society.

Filosofian tohtori Pasi Enges on folkloristiikan yliopistonlehtori Turun yliopistossa. 